潰瘍例が 13 肢である.

再建術式はバイパス術が 43 例，パッチ形成術が 6 例, 血栓除去術が 1 例である. バイパス術では全例自家大伏 在静脈を使用し, in situ とした 3 例以外はすべて逆転 静脈グラフトとした.

バイパス術 43 例中 8 例が閉塞し，このうち 1 例が肢 切断となった．また別に中枢側バイパスの人工血管感染 のために肢切断となったものが 1 例あった。累積開存率 は， 1 年 $83.6 \%, 5$ 年 $76.6 \%, 10$ 年で $76.6 \%$ であり, 救肢率は $95.5 \%$ であった。

下腿三分枝動脈の外径は，本邦人の大部分では 2.0 $\mathrm{mm}$ 以下であり，肉眼やルーペ使用下では血管壁の性状 確認や，正確な吻合操作を行うことが困難である。乙れ 飞対し顕微鏡を使用することにより，血管内膜の状態を 詳細に観察するととができ，正確な運針が可能となる. また不用意な操作で血管内膜を傷つけること屯避けるこ とができる．とのととは長期開存成績にも良好な影響を 与えるあのと考えられる.

顕微鏡下血行再建では顕微鏡を操作しうる十分な視野 を平面状に確保するととが重要であり，この点より到達 法は内側アプローチが有利と思われる．また再建部位は 脛骨・腓骨動脈幹を合めた下腿上 $1 / 3$ の中枢動脈々下腿 下 $1 / 3$ の遠位動脈が手術操作の点より適当と考えられ る. 顕徽鏡の特徽として視野の桩大率を自由に変更でき るととがあり，微細な観察を必要とする場合は強拡大と し，ある程度の視野の広さを必要とする場合は拡大率を 下げて術野を確保するととが可能である。われわれは動
脈切開後, 内膜の状態を観察する場合は 10 倍拡大とし， 吻合操作時には 5 倍に拡大するようにしている.

顕微鏡下の血管吻合は，端端吻合が一般的であるが， 端側吻合であとくに支障なく吻合可能である．とくに自 家静脈による再建の場合，動脈之の吻合口径差ああり端 側のほうが吻合しやすいと思われる。われわれは吻合部 中枢側の逆行性灌流や側副路温存のために原則として端 側吻合を行うようにしている.また縫合糸は 7-0 プロレ ン糸を使用し，初期には確実な吻合を心掛けるために結 節縫合としていたが，顕微鏡下手技に習熟するにつれ連 続縫合でも成績が安定してきたため，現在は動脈外径が $1 \mathrm{~mm}$ 以上あれば連続縫合であ十分縫合可能であると考 えている.

\section{結語}

以上症例を供覽し，当科での手術成績について報告し た．顕微鏡の使用は，最初は準備が煩雑で，またかえっ て吻合しにくいように思われるが，慣れるに従いこのよ うな印象は薄らいでくる，顕微鏡はルーペのように拡大 率が固定しておらず，視野の大きさを自由に変更できる という大きな利点がある。手術は原則として, ある程度 の修練を積めば誰むが同様にできるようなものでなけれ ばならないと思われるが，微小血管吻合は現在のところ 特殊技術のよう飞考えられている。しかし顕微鏡を使用 することにより安定した手術成績が得られるようになれ ば，血管吻合はより一般的な手術となるのではないかと 期待される.

\title{
CS-II-5 下腿動脈への血行再建術
}

\section{山梨医科大学 第 2 外科 \\ 神谷喜八郎上野 明古屋隆俊}

\section{手術成績とグラフト不全例の検討}

慢性下肢動脈閉塞に対する下腿三分枝動脈以下へのバ イパス術は，1983 年 10 月より 1990 年 12 月までの期間 に 14 例経験した. 対象疾患はバージャ一病 (以下 TAO) 6 例, 閉塞性動脈硬化症 5 例, 塞栓血栓症 3 例であっ た. 下肢虚血の程度は間欠性跛行 4 例, 安静時疼痛 3
例，潰瘍・壇死 7 例であり，用いたグラフトの種類は 大伏在静脈 (以下 GSV) 11例 (reversed: 5, nonreversed : 5, in situ : 1), Dardik Biograft (以下 DB) 3 例であった，遠位吻合部を足関節部以下に求めたもの は 3 例（遠位後脛骨動脈：2, 足背動脈：1）, 中枢側吻 合部を鼠径勒帯より頭側に求めたすのが 3 例（大動脈， 総腸骨動脈，外腸骨動脈，各 1) あった. 


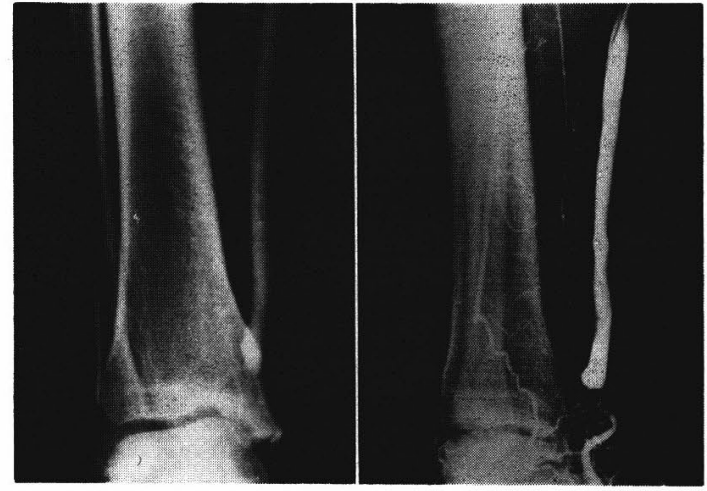

図 1 左：遠位後脛骨動脈バイパスの末梢側吻合部術 後 4 週後では吻合部には異常を認めない. 右：術後 2 年 7 か月でグラフト閉塞し，その直 後に血栓摘除をしたのちの術中造影では，吻合 部より末梢の動脈に著しい狭窄がみられた。

生命表分析によるグラフト一次累皘開存率は 1 年, 54 $\pm 14 \%, 5$ 年, $35 \pm 14 \%$ であり,グラフトの閉塞ないし 狭窄に対し，何らかの処置をしてグラフト開存を眓った あのを含めた二次累積開存率は 1 年, $77 \pm 12 \%, 5$ 年, $53 \pm 17 \%$ であった. 慢性塞栓症 2 例では 5 年, 7 年と 長期開存が得られ，他疾患に比へて明らかに成績が良好 であった。

狭窄，閉塞を含めたグラフト不全を 8 例経験したが， その原因は遠位吻合部狭窄 6 例，近位吻合部狭窄 1 例, グラフト压迫 1 例であった。

遠位吻合部狭窄による閉塞の 2 例（いずれもバージ ヤ一病）では, グラフト血栓摘除後の造影で, そのもっ とも狭窄の強い部位は吻合部末梢側の動脈にみられた (図1).そのうちの1例では狄窄部を切除し, 末梢へ rebypass しえたが，このとき採取したもっとも狭窄の 強い部位の病理組織像では，動脈内膜の著しい肥厚がみ られた(図 2)。このととは，遠位吻合部狭窄の一因とし て，術中の vessel loop による旁引が動脈壁に何らかの 損傷を引き起とし，これが誘因となって内膜肥厚を生じ るという可能性を示唆した。

遠位吻合部狭窄の他の 2 例では，端側吻合の吻合角度 がどちらかというと直角に近く，造影上グラフトから末 梢の動脈への移行が滑らかでないとと，また，グラフト 圧迫の 1 例は大動脈・前脛骨動脈バイパス例で，座位に よる屈曲が閉塞原因として考えられた。

てのような経験のうえで，現在用いている手術手技を 供覧し，考察を述べる.

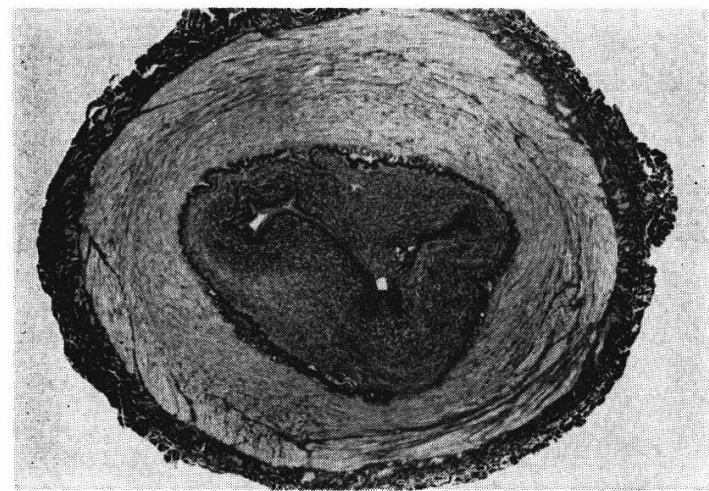

図 2 切除した標本では, もっとも強い狭窄部は吻合部末 梢の動脈であり, そこには全周性に著しい内膜肥厚 がみられた。

\section{症例と手術の概要}

症例 : 81 歳の男性で, 右足の安静時疼痛, 足背部難 治性皮膚炎，運動時足関節痛を主訴とした閉塞性動脈硬 化症である，患肢の下肢動脈造影では，外腸骨動脈は鼠 径靱帯直上で閉塞し，総大腿-浅大腿-滕窩動脈および前 脛骨動脈は造影されず，腓骨後脛骨動脈幹以下が比較的 良好に造影され，pedal arch も保たれていた。

手術の概要 : 鼠径鞋帯の頭側で外腸骨動脈を㓦離し, この部位が全周性に柔らかいととを確認して，乙こを端 側吻合の中枢側吻合部とするとととした。下腿内側ほぼ 中央で後脛骨動脈を前面のみ露出し，剝離は動静脈の共 通血管鞘までにとどめた．忠側の大伏在静脈グラフト (GSV) は末梢で分岐し，直径 $2 \mathrm{~mm}$ 弱と細かったので, 対側より採取することとした。あらかじめ GSV 周囲に 塩酸パパベリン加生理食塩水を浸潤させて GSV グラフ トの spasm 防止とした. 採取した GSV 末梢に弁付き カニューレを挿入し，加圧しすぎないように注意して， ヘパリン加自家血を注入して GSV の拡張を行った。筋 膜下にトンネルを作成後ヘヘパリン $50 \mathrm{U} / \mathrm{kg}$ を静注し， 5-0 polypropylene 糸で中枢側吻合を行った. グラフト の toe と heel のみ 3 針の結節縫合とし, 他は連続縫合 とした. 共著者の古屋が Hall の valve stripper を改 良して考案した，4枚刃を有する弁切開刀（図 3 ）を GSV 末梢端より扦入して，静脈弁を切開した．動脈 血の良好な拍動性流出が得られれば良しとしている. GSV を筋膜下ルートで末梢吻合部へ誘導した後，エス マルヒ駆血帯を足部から膝上まで巻き上げ，空気ターニ ケット $300 \mathrm{mmHg}$ で駆血した。吻合は中枢側と同様に 6-0 polypropylene 糸で行った. 末梢側吻合には好んで 


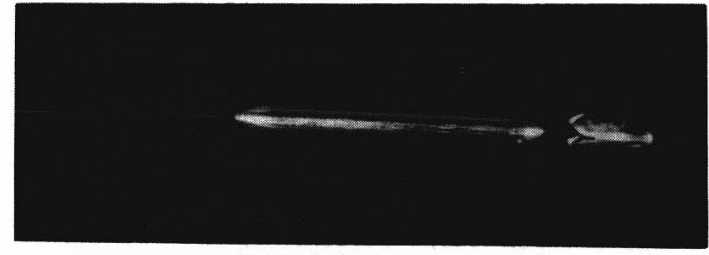

図 3 先端を鋭的な 4 枚刃とした Hall 改良型の弁切開刀

microsurgery 用のピンセットを使用している. 電磁流 量計で測定したグラフト流量は $240 〜 280 \mathrm{ml} / \mathrm{min}$ であ った.

術後の経過 : 術後 7 か月後の動脈造影では, 遠位吻合 部で host artery がグラフトに引っ張られる形になった が,グラフトから末梢動脈への移行は滑らかで狭窄はみ られず, ankle pressure index は術前の0.21から, 術 後 1.16 と増加した. 術後 9 か月現在, グラフトは開存 し, 安静時疼痛と足背部皮虐炎は軽快し，運動時足関節 痛もリハビリ後消失している.

\section{考察}

われわれの下腿動脈へのバイパス術のうち，鼠徍靱帯 より上に中枢吻合部を求めたものが 3 例あったが，ここ に提示した症例を除く他の 2 例は，ともに足部潰瘍を有 する広範な動脈閉塞の症例で, 他施設で患肢の血行再建 術を受けた睡往があったとともあって，大動脈あるいは 総腸骨動脈からの DB による long bypass となった. と あに術後早期に 2 回以上のグラフト閉塞を起こし， 1 例 はグラフト感染もあったため, 中枢側吻合を移したが, 二次開存はそれぞれ 4 年 8 か月他病死するまでと, 6 年 以上の開存が得られ, 救肢目的を果たした。 遠隔時にグ ラフト瘤形成の問題は残るとしても, 救肢目的であれ ば，DB による二関節を越える long bypass あ, 体位に よる関節部の届曲に配慮してグラフトの長さに余裕を持 たせる工夫をすれば，考慮すべき術式であろう．

慢性塞栓症の成績が良かったととは当然とむいえる が, これは吻合部, とくに末梢吻合部は病変の可及的に 少ない部位を選ぶべきととを示唆している. 現在は，グ ラフトが長くなっても，あるいは関節を越えてむ，でき るだけ動脈壁の性情が良い所を吻合部に選ぶことを第一 に優先すべきと考えている.

末梢側吻合部狭窄がグラフト不全の主因であったが， そのなかで vessel loop による動脈の牽引が狭窄形成の 誘因となりうるととが示唆されたととにより, 最近は末 梢吻合での血流遮断は多田らの報告に従い，エスマルヒ 駆血帯による方法”を採用している．との方法を採用し
てからまだ日が浅いが，ここで提示した症例では，末梢 吻合部の動脈が引っ張られた形になった. エスマルヒ駆 血帯で軟部組織が圧縮され，吻合が終了して駆血を解除 したあと, 軟部組織が膨張してもとに戻り，本例が皮下 ルートであったことああり，結果的にグラフトが短くな ったものと思われる. 本法を用いるときは，グラフトを 長めにとるか; 多田らが指摘しているように衣，エスマ ルヒ駆血帯を巻く前に, あらかじめグラフト吻合部に印 を付けておく配虑が必要である. この方法の利点とし て，血流遮断による吻合部付近の動脈損傷の可能性がな いことのほかに, 容易に完全無血野が得られ, 良好な視 野で確実な縫合操作ができることああげられる.

グラフトは皮下ルートを多用してきたが，グラフトと 端侧吻合した動脈との角度が直角に近いことはグラフト 閉塞の一因とも考えられたので, 現在は, グラフトが吻 合する相手の動脈としばらく並走してから，吻合部では 末梢側の動脈へ滑らかに移行するような角度とするほう が良いと考え，皮下ルートにはこだわっていない，吻合 孔の大きさも，乙のような考えから，末梢のグラフト径 の 2.5 倍以上としている.

グラフトは大伏在静脈を第一選択とし, 前期は reversed GSV を使用し，後期には non-reversed GSV に変更した. Non-reversed GSV では, グラフト径と吻 合すべき動脈径との mismatch が小さいという利点があ る一方, 静脈弁を破壊するために, 何らかの操作をグラ フト内腔から加えねばならない欠点がある. 弁破壊には 最初, Hall の valve stripper ${ }^{2)}$ を使用したが, これは 2 枚刃であるため, 一回の操作ではすべての弁を破壊で きず, 方向を変えて通常 2,3 回静脈内を往復させねば ならなかった，そこで現在は，先端を 4 枚刃として一回 の操作ですべての弁破壊ができるように工夫したものを 用い, 目的を果たしている.

われわれが開発した弁切開刀の有用性については, 弁 破壊のためにはグラフト内腔からの操作を要するという 根本的な欠点屯含めて, 今後の検討が必要である.

\section{結語}

下腿動脈へのバイパス術の 1 年および 5 年グラフトー 次累積開存率はそれぞれ $54 \pm 14 \% ， 35 \pm 14 \%$ と良好で はなかった. 手術成績向上のために, 以下の点を重要と 考え, 今後の方針とした.

1）吻合部にはできるだけ病変の少ない部位を選ぶこ とを最優先とする.

2）末梢吻合部の動脈損傷をできるだけ少なくするた 
めに，剝離を最小限とし，血流遮断には，エスマルヒ駆 血帯を用いる.

3）末梢吻合部では，グラフトから末梢側の動脈へ滑 らかに移行するようにし，皮下ルートにはこだわらない。
文 献 1) 多田祐戟ほ分: 手術 43: 193, 1989. Skagseth, E. et al.: Scand. J. Thorac. Cardiovasc. Surg. 7: 53, 1973.

\title{
CS-II-6 脛骨動脈領域に対する balloon angioplasty
}

\author{
舞子台病院 外科, 循環器科* \\ 前田雅道鈴木洋*
}

近年の balloon angioplasty (以下 BA) の発展はめ ざましいものがあり，対象血管は，冠動脈をはじめ，腹 部動脈, 下肢動脈領域へと広がり, その結果も良好で, 血行再建法の一つとして確立されてきた れわれは，脛骨動脈領域へこの BA を試み，良好な結 果を得たので，その手技を述べるとともにその有用性に ついて検討を加えた.

対象

平成元年 3 月より, 平成 3 年 4 月までの 26 か月に行 われた症例, 18 例で, 男性 11 例, 女性 7 例, 年龄は, 52 歳から 86 歳, 平均 73.1 歳であった. 全症例は, DSA (i.v.) にて竛断され，BA までに抗血小板剂が， 投与された. DSA (i.v.)ならびに形成術には，GE 社 製 DF 5000 を使用した. 平成 2 年度までの症例は，力 テーテル Schneider 社製 $4.3 \mathrm{~F}$, バルーン長 $17 \mathrm{~mm}$, 径 $3.5 \mathrm{~m}$ を, 平成 3 年度より Schneider 社製 $4.5 \mathrm{~F}$, バルーン長 $20 \mathrm{~mm}$, 径 $3.5 \mathrm{~mm}$ を使用した. ガイドワ イヤー0.021 Magnum-Meier ガイドワイヤーと 0.018 ガイドワイヤーを用いた. またシースインロデューサー を順行性に挿入するため 0.035 ラジフォーカスガイドワ イヤーを用いた。

術前の DSA において血栓の存在が疑われる症例飞つ いては，大腿動脈を露出し，血栓除去術を施行後，BA を施行, その他の症例については, 経皮的 BA を試み た.

シースインロデューサー $(5 \mathrm{~F})$ を挿入後, ヘパリナイ ズ（2000３000 単位）を行い, 閉塞部位の確認のため, 側枝より造影剤を注入した. Multiple lesion 狭窄通過 にはままず Magnum-Meier ガイドワイヤーを使用し
て, 狭窄部通過を試み, 狭窄度の強い short lesion に は，0.018ガイドワイヤーを試みた，狭窄部のカテー テル通過は, 慎重に行い, その後, バルーンを $5 \sim 7$ 気 圧，時間は，拡張開始から 60 秒を原則とした。抎張後， ガイドワイヤー捚入に困難な部位の場合には，ガイドワ イヤーを留置したまま, インロデューサー側枝より造影 剂を注入し，抎張評価を行ったのち，次の狭窄部にすす んだ. BA 終了後, ふたたび確認のため造影を側枝より 施行した. 術後当日のみ, ベット上安静を厳守したが, 翌日より, 歩行開始とした. アルガトロバン, $\mathrm{PGE}_{1}$, or lipo-PGE 1 は，当日より開始し，退院までの数日間投 与. 抗血小板剤等の経口剂は退院後も継続した。

\section{結 果}

脛骨動脈領域を(1)〜 (4)の部位に区分し，その狭窄の程 度を, short lesion, multiple lesion, totally blocked lesion（未梢が造影されててない）に分類した（図1).

18 症例で, 病変部位は, 36 か所, 一症例あたり二つ の狭窄を認めた．部位別，狭窄度による成功率は表 1 の ごとくで, short, multiple lesion については, それぞ

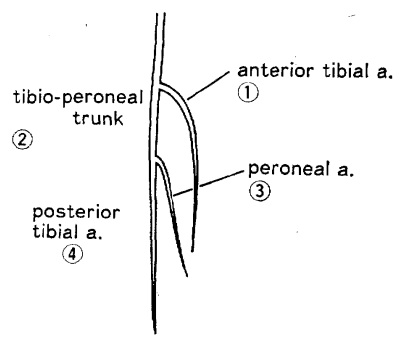

short lesion multiple lesion totally blocked lesion 